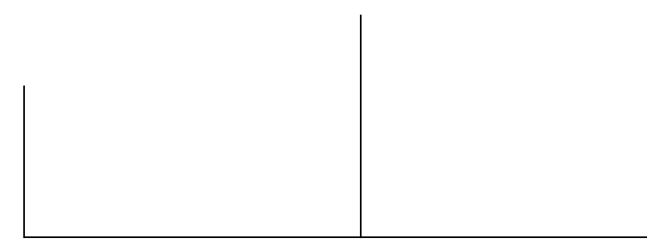

“Putting DSM-IV in perspective” (editorial)

G. Tucker

The American Journal of Psychiatry

1998

\title{
Por uma visão crítica do DSM-IV
}

O editorial do The American Journal of Psychiatry de fevereiro deste ano, trata de uma questão decisiva para todos os que se interessam pelo campo da psicopatologia neste final de século, ou seja, ele realiza uma análise crítica das conseqüências do DSM-IV para a clínica psiquiátrica em geral.

O artigo afirma que a introdução do DSM-III, em 1980, constituiu um momento importantíssimo para a história da psiquiatria, fornecendo pela primeira vez critérios diagnósticos explícitos, objetivos e bem definidos para os transtornos mentais permitindo, assim, a realização de uma enorme quantidade de pesquisas, especialmente no campo dos transtornos ansiosos e afetivos. Graças à uniformidade dos grupos que esse sistema definia, foram possíveis enormes avanços nos conhecimentos epidemiológicos e sobre a eficácia de diferentes tratamentos. "De fato, o novo processo diagnóstico do DSM tem dominado a pesquisa, o ensino e a prática contemporânea da psiquiatria.” Na verdade, o diagnóstico pelo sistema DSM tornou-se o principal objetivo da prática clínica psiquiátrica. Contudo, afirma o editorialista, "nosso processo diagnóstico atual pode também estar arruinando a essência da psiquiatria”. Estaria na hora de se fazer uma correção de percurso.

"Muitos têm chegado a acreditar que estamos lidando com transtornos claros e distintos mais do que com agrupamentos arbitrários de sintomas. Estamos atualmente presos por nossa própria retórica pelas companhias de assistência médica que sustentam que se os sintomas do paciente preenchem os critérios de um episódio depressivo maior, então o tratamento deve ser feito com as drogas X ou Y.”

O artigo lembra que em psiquiatria não importa quão científica ou rigidamente sejam usadas as escalas para estimar os sintomas dos pacientes; no estado atual dos conhecimentos, o que se está fazendo não passa de reconhecimento de certos padrões de comportamento. 


\section{RESENHAS}

DE ARTIGOS

Como conseqüências do abuso do DSM-IV no contexto psiquiátrico contemporâneo, são apontadas:

1) a perda do contato com o paciente e com sua história;

2) freqüentemente, o que é tratado é o diagnóstico e não o paciente;

3) o estudo da psicopatologia tornou-se praticamente inexistente e

4) o foco estrito no diagnóstico tem tornado a prática da psiquiatria "maçante" (boring).

O texto é encerrado com o comentário de que o DSM-IV tem constituído um grande avanço em psiquiatria, mas fornece apenas uma parte da informação necessária, "a outra parte é a história do paciente ou sua narrativa”. O artigo é, pois, um libelo a favor da clínica psiquiátrica, da escuta do sujeito que sofre e do retorno ao estudo da psicopatologia: não é a toa que o nome de Jaspers é citado duas vezes em um texto de não mais de três páginas. Trata-se não de uma recusa dos progressos obtidos com os métodos diagnósticos contemporâneos, mas um apelo ao bom senso, de modo que a prática psiquiátrica volte a ser algo de instigante e não uma mera aplicação acrítica e artificial de convenções classificatórias.

"The split brain revisited"

M. Gazziniga

Scientific American

July 1998, 35-39

\section{Três décadas de estudos sobre o "cérebro dividido"}

O Scientific American de julho passado traz um importante trabalho de Michael Gazzinaga, neurocientista que há quase trinta anos revolucionou os estudos sobre o cérebro descrevendo, juntamente com outros três colegas, o que acontecia com o funcionamento mental quando a principal via de comunicação neuronal entre os hemisférios cerebrais ficava interrompida. Essa "ponte" neuronal, chamada corpo caloso, é a principal responsável pela integração das 
atividades dos dois hemisférios. Sua ruptura - anatômica ou funcional estabelece um estado de coisas no qual cada metade do cérebro passa a funcionar de modo praticamente independente em relação à outra, permitindo que se conheça melhor as especificidades neurofisiológicas de cada uma.

Tornou-se claro, por exemplo, que em tais circunstâncias a informação visual não podia mais mover-se entre os dois lados. "Se nós projetássemos uma imagem para o campo visual direito - ou seja, para o hemisfério esquerdo, onde a informação do campo direito é processada - os pacientes eram capazes de descrever o que viam. Mas quando a mesma imagem era apresentada ao campo visual esquerdo, os pacientes tinham um branco: eles diziam que não viam nada”. Inúmeras outras descobertas foram relatadas. A mais amplamente difundida foi a de que os dois hemisférios controlam aspectos muito diferentes da linguagem e da ação. Cada metade tem sua própria especialização: o cérebro esquerdo é dominante para a linguagem e para a fala, enquanto o cérebro direito é especializado nas atividades visio-motoras. Contudo, o autor lembra que a secção do corpo caloso não interrompe a comunicação inter-hemisférica de modo absoluto, pois permanecem vias menores de contato anatômico através das chamadas "comissuras" cerebrais, o que limita as extrapolações que podem ser feitas.

$\mathrm{O}$ artigo discute o que de novo foi descoberto a esse respeito desde então. Observou-se, por exemplo, que apesar da especialização de cada hemisfério, há um grande potencial de plasticidade e de variação individual. $\mathrm{O}$ aumento do conhecimento sobre a metade direita mostrou que, apesar de esta não possuir uma capacidade de sintaxe sofisticada, é altamente provável que ela possa ampliar consideravelmente seus conhecimentos lexicais. As lesões no hemisfério esquerdo são, de longe, muito mais deletérias para a função da linguagem do que as do direito. Mas já foram descritos casos de pacientes que após vários anos de destruição parcial ou completa dessa parte, puderam desenvolver uma escrita "direita".

Da mesma forma, descobriu-se que os dois hemisférios diferem quanto a suas formas de processar novos dados. O hemisfério esquerdo possui uma maneira mais afetiva para lidar e interpretar a memória: “Quando confrontadas a novas informações, as pessoas geralmente lembram-se do que elas realmente experimentaram. Quando questionadas, usualmente lembram de coisas que não fez parte verdadeiramente da experiência. Se tais testes são dados a pacientes com o cérebro cindido, o hemisfério esquerdo gera muitos relatos falsos. Mas o direito, não; ele fornece uma reprodução mais verídica”.

O futuro da pesquisa nessa área é apontado na seguinte direção: tratar do fato de que embora ambos hemisférios possam ser vistos como conscientes, a consciência do inventivo e interpretante cérebro esquerdo ultrapassa de longe o cérebro direito, realista e literal. 
RESENHAS

DE ARTIGOS

“Psychopathology and primitive mental states"

R. Caper

International Journal of Psycho-Analysis

1998, 79, 539-551

\section{Psicopatologia e estados mentais primitivos}

Um artigo recentemente publicado no International Journal of PsychoAnalysis retoma a questão dos artefatos introduzidos na psicopatologia psicanalítica em função de se assumir certas hipóteses sobre as fases precoces do desenvolvimento psíquico.

Nesse texto instigante (colocado em discussão na página do Journal na internet - http://www.ijpa.org), o autor discute o conceito psicanalítico de "estado mental primitivo" com o intuito de saber se doenças psíquicas do adulto devem ser vistas como uma regressão ou uma fixação a esses supostos estados, tal como propõem inúmeros pesquisadores. Partindo do ponto de vista de que o termo "estado mental primitivo" refere-se a uma etapa precoce do desenvolvimento psicológico normal, o texto sustenta a idéia de que em nenhum caso a psicopatologia representa uma expressão direta de retorno ou fixação a um modo primitivo de funcionamento. Nesse caso, a situação psíquica infantil e a psicopatologia teriam diferenças qualitativas radicais, sobretudo quanto ao fato de que, nos casos patológicos, estariam em jogo forças suficientemente destrutivas para impedirem o aprendizado com a experiência, levando a um desenvolvimento doentio.

O autor fala de uma "falácia teórica" que consiste em se pensar que a psicopatologia adulta deriva da situação psicológica normal da criança, esqueçendo-se da especificidade patologia infantil. 


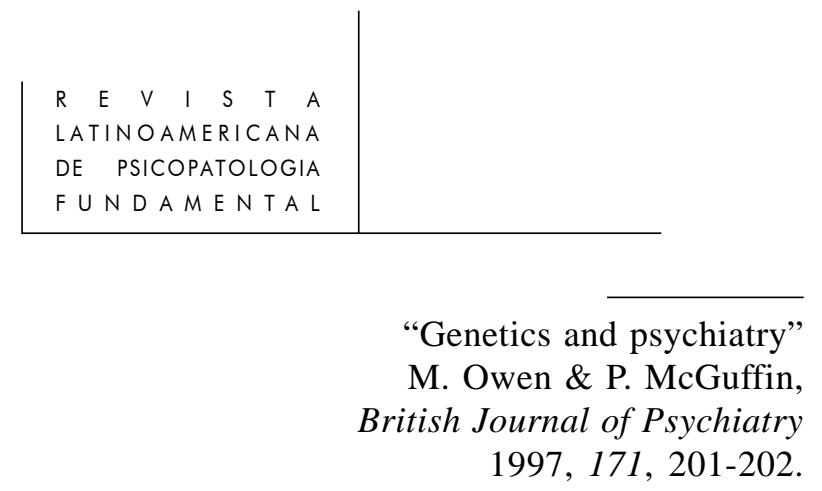

\section{Genética e psiquiatria}

O editorial do British Journal of Psychiatry trata do tema da incompreensão do lugar da genética no campo da psiquiatria contemporânea. Afirma-se que uma apreciação realista do impacto da pesquisa genética para a psiquiatria só poderá ser alcançada quando um certo número desses mal-entendidos (ou, por vezes, mera ignorância preconceituosa) puder ser superado. Os autores afirmam que é um consenso generalizado entre os pesquisadores desse campo que a herança dos transtornos psiquiátricos mais comuns é complexa e provavelmente reflete a interação de inúmeros genes com fatores ambientais: "Em outras palavras, a doença mental não é 'causada' pela infra-estrutura genética da pessoa e é provável que cada um dos genes individuais envolvidos vão jogar apenas uma pequena parte para conferir susceptibilidade ou predisposição”.

Nesse mesmo número do British Journal há um importante artigo de M. Rutter e R. Plomin, intitulado "Opportunities for psychiatry from genetics findings” que retoma em detalhes algumas das falsas concepções correntes sobre a genética psiquiátrica, tais como as idéias de que uma alta predisposição hereditária significa que intervenções a partir do meio seriam inefetivas; de que os efeitos genéticos nas doenças não seriam afetados por intervenções ambientais e de que os efeitos genéticos são determinantes. O artigo mostra que os efeitos da natureza e os da cultura não são separados e propõe que nos processos causais da psicopatologia deve-se pensar num interjogo entre essas dimensões.

Estes dois trabalhos são indispensáveis para os que desejam ter uma visão crítica do que efetivamente constitui o impacto dos progressos contemporâneos da genética na compreensão da psicopatologia. 
"Méthodologie et intérêt du unique en psychopathologie" J.-D. Swendsen \& M.-L. Bourgeois

\section{A metodologia do caso único em psicopatologia: novas técnicas}

A maior parte das análises quantitativas de grandes amostragens examina as características gerais dos transtornos mentais para a maioria das pessoas. Ao pesquisador empírico cabe a tarefa de descrever em detalhes a experiência e os processos individuais em jogo nesses transtornos. Esse artigo publicado nos Annales Médico-Psychologiques apresenta o Método de Amostragem de Experiências (ESM) que permite, através de um modelo linear hierárquico, se formalizar esses achados individuais permitindo não apenas uma nova forma de estatística da análise dos dados, mas também uma nova conceitualização nas tentativas de compreender as experiências do indivíduo.

O texto contém um quadro com exemplos recentes de investigações ideográficas e fenomenológicas baseadas na metodologia empírica e formalizados pelo ESM. O texto é importante para aqueles que se interessam pelas novas fronteiras metodológicas no campo da psicopatologia. 